\title{
THE EFFECT OF TOPDRESSING AND LIMING ON UPTAKE OF MINERAL NUTRIENTS IN PASTURE
}

\author{
K. J. McNaught \\ Ruakura Soil Research Station, Hamilton
}

\section{Summary}

The effect of a fertilizer element on its concentration in grass/ legume herbage depends mainly on (1) quantity applied, (2) the degree of deficiency, (3) whether the added nutrient is "fixed" or leached and, (4) whether the fertilizer changes the proportion of clover to grass.

Fertilizers increase concentrations of major elements in herbage much more in the deficiency range than when levels are already high. However, plants appear to lack the ability to restrict intake of the trace elements.

In a stocking rate $x$ lime trial, in which lime increased pasture yields, lime responses in animal production were found only at the high stocking rate, indicating a feed quantity, rather than quality effect. This was confirmed by plant analysis.

\section{INTRODUCTION}

ConCentration of a nutrient in pasture'herbage depends on (1) plant species or variety, (2) climate, (3) stage of growth or maturity, (4) soil nutrient status, (5) soil properties.

However, since fertilizer applications cannot change climate and usually have only minor effects on plant maturity and soil properties such as retention of phosphate or sulphate, their greatest effect is on the supply of available nutrients.

\section{EFFect of SoIL Nutrient Status}

When the lack of a plant nutrient is retarding growth, nutrient uptake by plants from applied fertilizer is relatively efficient and both concentration and dry matter yield increase appreciably. As soil nutrient status increases from adequacy to excess, uptake of potassium from added fertilizer falls off progressively and becomes very small when the concentration in the plant is two to three times the plant's needs (McNaught, 1959).

There are indications from sand and solution culture work that this rapid reduction in uptake can be expressed by the statement that the concentration of a nutrient such as potassium, 
calcium or magnesium in the plant is linearly related to the logarithm of the solution concentration, This is indicated for calcium in work of Loneragan and Snowball (1969). A similar relationship should exist between concentration in the plant and available nutrient in the soil. Good evidence for this has been obtained for magnesium in a series of experiments conducted by M. R. J. Toxopeus on a pumice soil, Waipahihi sand, ranging in soil magnesium status from very low to high.

This ability to exclude too great an excess of nutrient, appears to be lacking in the case of trace elements. Manganese is often present naturally in plant tissues in amounts 5 to 10 times the plant's needs. With topdressing it is easy to increase molybdenum in pasture plants in some soils to 10 to 20 times normal levels, or selenium 200-fold, without any apparent adverse effect on growth, but with serious implications for stock health (Cunningham ef al., 1956 (Mo) ; Grant, 1965 (Se)).

\section{CONCENTRATIONS OF APPLIED MAJOR ELEMENTS}

The size of concentration increase from fertilizer will clearly depend on the degree of deficiency and on the amount of nutrient applied, relative to needs. A $10,000 \mathrm{~kg} / \mathrm{ha}$ dry matter crop of ryegrass requires about $400 \mathrm{~kg}$ nitrogen and $250 \mathrm{~kg}$ potassium compared with only $40 \mathrm{~kg}$ phosphorus, $30 \mathrm{~kg}$ sulphur, $20 \mathrm{~kg}$ calcium and $15 \mathrm{~kg}$ magnesium. Superphosphate contains 9 to $10 \%$ phosphorus, sulphate of ammonia or nitrolime 20 to $24 \%$ nitrogen, but potassium chloride contains 48 to $50 \%$ potassium. The fertilizer equivalents of the herbage $\mathrm{N} \mathrm{P} \mathrm{K}$ contents are therefore about $2000 \mathrm{~kg}$ sulphate of ammonia, $440 \mathrm{~kg}$ superphosphate and $500 \mathrm{~kg}$ potassium chloride.

N ITROGEN

In view of the very high nitrogen needs of grasses and the fact that only 20 to $24 \%$ of the weight of sulphate of ammonia or nitrolime is nitrogen, rates such as $125 \mathrm{~kg} / \mathrm{ha}$ or $1 \mathrm{cwt} / \mathrm{acre}$ of these forms of nitrogen are physiologically quite small and may barely be sufficient to correct a nitrogen deficiency in the standing herbage before this is removed by grazing and the nitrogen excreted elsewhere. It is not surprising, therefore, that applications of this size usually have only fleeting effects on yield and composition. Furthermore, part of the applied nitrogen, especially from nitrate,, may be washed from the soil by leaching rain. 


\section{S U L P H UR}

Sulphur needs in the plant are less than one-tenth those of nitrogen. Normal rates of a sulphate-containing fertilizer such as superphosphate theoretically supply more than enough sulphur nutrient. Sulphate-retentive soils receiving heavy dressings of superphosphate can accumulate excess sulphate, resulting in very high concentrations of both total sulphur (McNaught and Chrisstoffels, 1961) and sulphate-sulphur (Dijkshoorn et al., 1960) in the herbage, for example, $0.6 \%$ and $0.4 \%$, respectively.

\section{PHOSPHORUS}

Although pasture phosphorus concentration needs are only about one-tenth those of nitrogen and one-fifth those of potassium, relatively high rates of application of superphosphate have to be used to correct deficiencies because the phosphorus content of superphosphate is only 9 to $10 \%$. -Furthermore, phosphate is inefficiently absorbed by pasture plants from soils, especially highfixing soils, even within the deficiency range for plant growth, because of strong adsorption or retention by soil colloids. Much more has to be applied than the extra uptake (uptake is concentration $\mathbf{x}$ yield) needed to achieve optimum yield. Usually herbage phosphorus levels increase appreciably with increasing rates of phosphate fertilizer, especially when plant phosphorus levels are low, but frequently significant yield responses to phosphate are obtained at higher levels of plant phosphorus, accompanied by little or no change in phosphorus concentration in the herbage. It is suspected that the function of the phosphate in such cases is to suppress aluminium toxicity, rather than to correct true phosphorus deficiency. The fact that higher optimum levels of phosphorus are usually found in herbage on high fixing soils than in plants grown in sand cultures also suggests some such indirect function of phosphate in many soils (McNaught, 1970).

\section{POTASSIUM}

As 48 to $50 \%$ of the weight of potassium chloride is potassium element, a typical maintenance dressing of only $125 \mathrm{~kg} / \mathrm{ha}$ or $1 \mathrm{cwt} /$ acre actually supplies a substantial amount of potassium nutrient.

Potassium concentrations in pastures always increase appreciably when a deficiency is corrected, but increases can be quite small in the "luxury" or excess uptake range. 


\section{Calcium and Magnesium}

By contrast, calcium and magnesium give the impression of being relatively inefficiently absorbed. Calcium deficiency in pasture plants, however, is rare and magnesium deficiency is very uncommon outside the Rotorua-Taupo region. In most pastures calcium levels are already two to three times plants' needs, while magnesium is usually one and a half to two times as high as needed for plant growth. It is not surprising, therefore, that uptake of magnesium from applied fertilizers or calcium from lime is usually quite small.

\section{EFFECT OF FERTILIZERS ON LEVELS OF OTHER NUTRIENTS}

Any treatment which increases the proportion of clover to grass will increase especially the calcium and boron concentrations in the mixed herbage because the concentrations of these elements in clovers are normally two to three times as great as in grasses.

In general, if two nutrients such as phosphorus (P) and potassium $(\mathrm{K})$ are both deficient, application of $\mathrm{P}$, by stimulating some growth, will depress the concentration of $\mathrm{K}$ in the herbage, simply by dilution. However, if only $\mathrm{P}$ is deficient and $\mathrm{K}$ soil supplies are high, $\mathrm{P}$ application will have little or no effect on the concentration of $\mathrm{K}$ in herbage even when quite large yield responses to $\mathrm{P}$ result.

Some nutrients compete with others for entry into plant roots. The most consistent antagonism is the potassium depression of sodium, magnesium and calcium concentrations in herbage (McNaught, 1959). The effect on magnesium is less in clover than in grass. The size of the decrease is determined by the size of the increase in potassium concentrations. The reduction is therefore much greater when an acute potassium deficiency is corrected than when potassium concentrations in the herbage are already high. Typical effects on herbage composition which caa be expected from maintenance dressings of potash (usually about $125 \mathrm{~kg} / \mathrm{ha} / \mathrm{annum}$ ) are, for example, $15 \%$ reduction in sodium, $5 \%$ in magnesium and $3 \%$ in calcium, with possibly double these effects in the first month after application.

The claim is often made that magnesium fertilizers have to be used to get the best value from phosphate fertilizers. In Ruakura magnesium experiments on farm paddocks, topdressed at the recommended rates, exactly the same phosphorus levels were found in pastures with and without magnesium fertilizer. 


\section{EFFECTS OF I IME}

In three recent experiments on soils from pumice, and one on a peaty loam, where there were no growth responses even at soil $\mathrm{pH}$ values as low as $5.1,2500 \mathrm{~kg}$ lime $/ \mathrm{ha}$ (1 ton/acre) produced virtually no change in the major elements, apart from calcium which increased by $9 \%$. Manganese was reduced by $24 \%$ and molybdenum increased by $20 \%$. Zinc, copper and boron were slightly reduced.

On lime-responsive soils, lime often increases phosphorus in plants. This appears to be the result of raising the soil $\mathrm{pH}$ as magnesium carbonate produces similar effects.

\section{Fertilizers and Antmal Health}

In grassland farming, the main source of essential minerals for stock is the grazed herbage. Significant amounts of some elements, for example sodium, can be obtained from natural drinking water, and ingested soil can provide an important, though ill-defined, supplementary source of trace elements such as cobalt, as in the Morton Mains District in Southland. Most of the essential major elements, however, are provided by grass/ legume pasture grazed in situ or conserved and fed out as hay or silage. Clearly quantity of feed consumed is an important factor in daily intake of an essential element by the grazing animal. The first step, then, must be to provide the optimum amount of highly nutritious feed for the grazing animal using appropriate fertilizers to correct deficiencies for plant growth.

If this feed fails to provide enough of some element for stock needs, it will be necessary to supplement this in some wav. One possible method, but not necessarily the best, is to add this nutrient to normal fertilizer required for pasture production. This is successfully achieved with the trace element cobalt. There is no evidence that grasses need cobalt yet they take up enough from cobaltized superphosphate to supply the needs of sheep and cattle on cobalt-deficient soils. Iodine deficiency, however, is corrected by use of salt licks.

It is a different matter with a major element such as magnesium, which under some conditions appears to be needed by cows in much greater amounts than by plants. A magnesium concentration adequate for the growth of pasture plants can be too low in lush herbage about calving time to prevent "grass staggers" in cows. As already noted, it is very difficult to increase magnesium concentrations in plant tissues when levels are already 
adequate for plant nutrition; consequently, direct oral supplements of magnesium are more likely to succeed than topdressing for prevention of grass staggers.

The only appreciable increases in herbage magnesium levels found so far from applications of magnesium fertilizers, at low rates, have been on soils actually deficient in magnesium for plant growth, testing 1 to 4 units by the Departmental advisory soil testing procedure.

Numerous analyses at Ruakura indicate that lime increases calcium slightly but tends to reduce levels of trace elements of possible significance in animal health, such as cobalt, copper and zinc, and increases levels of molybdenum, especially when this has been applied, thus increasing the risk of molybdenum-induced

TABLE 1: MASTERTON STOCKING RATE $\times$ LIME TRIAL

(Average 3 years)

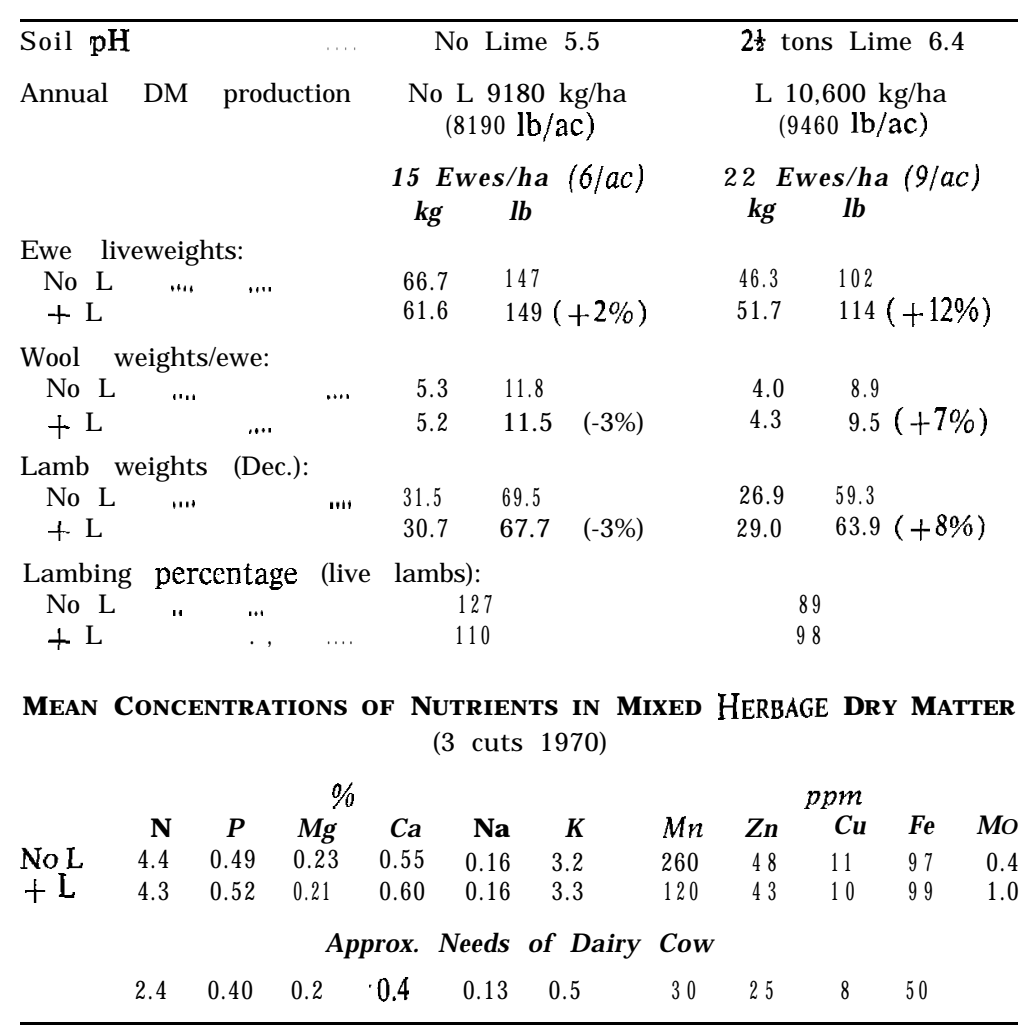


copper deficiency (Cunningham et al., 1956). There is no evidence that lime changes organic constituents of plants. A lime effect on animal production should therefore not be expected except where there is a dry matter yield response.

Pasture and animal production data and plant analysis results in the Masterton lime $x$ stocking rate trial conducted by $\mathrm{J} S$. Bircham and G. Crouchley (Table 1) indicate the absence of any herbage quality factor corrected by liming because there was no gain in per-animal performance at the low stocking rate, and instead emphasize the overriding importance of quantity of nutritious feed under high stocking rates.

\section{ACKNOWLEDGEMENTS}

Permission of J. S. Bircham and G. Crouchley to use interim data from the Masterton trial is gratefully acknowledged.

\section{REFERENCES}

Cunningham, I. J.; Hogan, K. G.; Breen, J. N., 1956: N.Z. Jl Sci. Technol., 38A: $225-38$.

Dijkshoorn, W.; Lampe, J. E. M.; van Burg, P. F. J., 1960: Plant and Soil, 13: $227-41$.

Grant, A. B., 1965: N.Z. Jl agric. Res., 8: 681-90.

Loneragan, J. F.; Snowball, K., 1969: Aust. J. agric. Res., 20: 465-78.

McNaught, K. J., 1959: N.Z. Jl Agric., 99: 442.

-- 1970: Proc. XIth int Grassld Congr.: 334-8 (see Table 1).

McNaught, K. J.; Chrisstoffels, P. J. E., 1961: N.Z. Jl agric. Res., 4: 177-96 (see p. 183). 